\title{
PROBLEMATIKA SEKSUAL DAN SOLUSINYA
}

\author{
Aina Noor Habibah \\ ainanoor@iaipd-nganjuk.ac.id \\ Dosen Ilmu Tasawuf IAI Pangeran Diponegoro Nganjuk
}

\begin{abstract}
Abstrak
Kemajuan ilmu pengetahuan dan teknologi memang mempermudah segala urusan manusia. Seseorang dengan mudah mengakses berita melalui internet. Baik berupa video atau yang lainnya. Namun dibalik kemudahan itu, ada beberapa dampak negatif yang tidak boleh dilupakan. Misalnya, semakin mudah orang mengakses informasi melalui internet, semakin mudah pula mereka mendapatkan video-video negatif. Dampak dari semua itu, dalam dunia modern, terutama pada negaranegara maju, tingkat kejahatan seksual lebih tinggi dibandingkan dengan negara-negara berkembang. Oleh sebab itu, agama harus memainkan peran agar kejahatan tersebut bisa di tanggulangi. Tulisan singkat itu mencoba menguraikan beberapa sebab kejahatan seksual yang terjadi dan menawarkan solusinya. Kesimpulan artikel ini adalah pertama langkah pencegahan agar tidak mendekati zina, kedua mengenakan bijab. Dalam persoalan homo-lesbi, al-Qur'an menawarkan solusi lewat pencitraan masyarakat bahwa 'hal tersebut keji'. Kedua dengan cara menikah secara wajar, yaitu dengan lawan jenis.
\end{abstract}

Kata kunci: solusi al-Qur'an, problematika seksual.

\section{A. Latar Balakang}

Perkembangan ilmu pengetahuan dan teknologi membawa dampak ganda, positif dan negatif. Dampak positifnya akan menjadikan manusia semakin mudah untuk beraktifitas. Saat ini seseorang yang ingin mendapatkan informasi apapun akan mudah didapatkan lewat internet. Baik dalam hal ekonomi, pendidikan, politik dan sebagainya. Kemajuan ilmu pengetahuan dan teknologi saat ini dimotori oleh Barat. 
Kemajuan ilmu pengetahuan dan teknologi yang dimiliki oleh Barat ini menyebabkan shock culture negara-negara Timur khususnya negara-negara Islam. Dampak dari kemajuan Barat ini akhirnya berimbas pada gaya hidup masyarakat. Mereka menganggap bahwa kebudayaan Barat adalah kebudayaan maju dan apabila ingin maju, maka 'harus seperti Barat' baik cara berfikir maupun dalam hal gaya hidup: style, fashion, social-associated, ethic dan sebagainya.

Imitasi terhadap Barat tanpa diimbangi dengan filterisasi ini kemudian memunculkan masalah baru yang tidak boleh di anggap remeh. Kasus kekerasan seksual, homo-lesbi dan sebagainya seakan menjadi hal yang biasa dilingkungan sekitar. Oleh sebab itu, persoalan degradasi moral seperti ini bukan hanya menjadi tanggung jawab pemerintah. Namun peran-serta tokoh agama juga dibutuhkan. Sebab, hal ini sudah menjadi penyakit sosial yang harus diselesaikan secara bersama-sama dengan cara dan porsinya masingmasing.

Menurut data dalam sebuah situs internet tentang sepuluh negara dengan tingkat kejahatan seksual tertinggi adalah Denmark, Zimbabwe, Australia, Kanada, Selandia Baru, India, Inggris, Amerika Serikat, Swedia, Lesotho (negara kecil bagian Afrika Selatan). ${ }^{1}$

Pada tahun 1999, Amerika menjadi negara tertinggi kejahatan seksualnya. Dalam salah satu seminarnya, Zakir Naik mengutip data resmi yang diperoleh dari FBI yang menyatakan bahwa "Data resmi FBI pada tahun 1999 tercatat sebanyak 102.555 kasus perkosaan, itupun hanya $16 \%$ dari sesungguhnya yang terjadi. Jika dijelaskan jumlah yang sesungguhnya ada 640.968 perkosaan di tahun 1999 saja. Jika dibagi dengan 365 hari/satu tahun maka yang terjadi adalah

http://news.okezone.com/read/2015/03/31/18/1126749/10-negara-kasuspemerkosaan-tertinggi data lain menjelaskan bahwa tingkat tertinggi adalah Amerika, Afrika Selatan, Swedia, India, Inggris. Lihat http://boombastis.com/negara-dengankasus-pemerkosaan-tertinggi/5797. Agama terbesar Afrika Selatan Kristen 47.526 .720 (82,25\%), Islam 869.470 (1,5\%) http://www.religion-facts.com/id/u3. di akses tanggal 21-11-2015; Sedangkan Afrika secara keseluruhan agama terbesar adala Kristen dan Islam. Mircea Aliade, The Encyclopedia of Religion. New York: Macmillan Publishing Company, 1987, 60-61. 
setiap hari sebanyak 1.756 orang diperkosa di AS pada tahun 1999 . Dan catatan lainnya adalah terjadi 1900 perkosaan setiap harinya. Itu artinya setiap satu menit terjadi 1,3 perkosaan. Saya sudah 30 menit disini, mungkin sudah perjadi 40 perkosaan disana? ${ }^{2}$

Persoalan kejahatan seksual kedua yang melanda dunia modern adalah menyebarnya penyakit sosial seperti homo ${ }^{3}$ dan lesbi. ${ }^{4}$ Penyakit ini harus di anggap sebagai kejahatan dan harus mendapatkan penanganan dari berbagai pihak. Sebab jika hanya satu pihak saja yang menangani penyakit ini, maka hasilnya kurang optimal. Pemerintah, tokoh masyarakat, tokoh agama bahkan dogma-dogma agama seperti kitab suci harus berperan aktif untuk menyajikan solusi dalam menghadapi penyakit sosial yang semakin hari semakin menunjukkan peningkatan. Untuk itu, tulisan ini akan berupaya menyajikan solusi yang ditawarkan oleh al-Qur'an dalam menghadapi penyakit sosial.

\section{B. Penyebab Problematika Seksual}

Dalam analisa penulis, ada banyak sebab mengapa seseorang terjerumus ke adalam kejahatan seksual. Pertama, lemahnya keimanan seseorang. Iman dalam pandangan penulis menempati posisi pertama dalam menanggulangi kejahatan seksual. Misalnya, jika ada dua pasangan laki-laki dan perempuan berada dalam keadaan sepi, gelap dan sebagainya, tentu situasi tersebut sangat berpengaruh terhadap 'pengambilan keputusan,' apalagi jika keduanya sudah sama-sama 'menginginkan' maka siapa yang dapat mencegahnya? Situasi dan kondisi bisa di ciptakan semantara pengawasan orang tua kepada anggotanya sangat terbatas. Untuk itu, dalam keadaan seperti inilah peran-serta iman kepada Tuhan menjadi kunci. Jika seseorang keimanannya kuat, ia tidak akan mengiyakan atau menciptakan

2 Zakir Naik, Wanita dalam Islam: Modern atau Ketinggalan Zaman. Malaysia: Islamic Research Fundation, 2000, CD, menit 10.

${ }^{3}$ Homo adalah orang yang melakukan hubungan seksual dengan sesama jenis (laki-laki dengan laki-laki).

${ }^{4}$ Lesbi adalah wanita yang terangsang nafsu seksualnya kepada sesama wanita. 
situasi itu, sebab dalam keyakinannya, hal merupakan dosa yang kelak akan dipertanggung-jawabkan dihadapan Tuhan.

Kedua, pengawasan keluarga. Keluarga memiliki peran yang sangat krusial dalam membina seluruh anggotanya agar mampu menghindar dari kejahatan seksual. Pengawasan orang tua meskipun tidak bisa 24 jam, tapi paling tidak akan meminimalisir angka kejahatan seksual terhadap anaknya. Sebab, keluarga adalah lingkup manajemen terkecil dalam sebuah sistem. Apabila sistem yang ada dalam keluarga tersebut kurang baik, maka rentan terhadap bahaya dari luar. Selain itu, pola pikir dan kebiasaan orang tua juga menjadi salah satu sebab terjadinya kejahatan seksual terhadap anak jika tidak tepat. Misalnya, jika seorang ibu terbiasa mengenakan pakaian ketat, tidak berjilbab, rok mini dan sebagainya, maka hal tersebut akan tertanam dalam pikiran si anak bahwa prilaku tersebut 'wajar' dan tidak masalah. Sehingga jika kebiasaan tersebut dibawa keluar, maka hal ini akan menjadi masalah.

Ketika, pergauluan. Seseorang bisa jadi memiliki pengetahuan agama yang baik dan dari keluarga yang baik pula. Namun, jika pergaulannya adalah tidak difilterisasi, maka bisa jadi orang yang memiliki bibit baik menjadi terkontaminasi oleh teman-teman yang tidak baik. Ibarat sebuah penjual minyak wangi, meskipun orang yang mendekatinya tidak membeli minyak wangi tersebut, ketika ia berdekatan dengan minyak wangi itu, maka sedikit banyak ia akan tertular wangi. Untuk itu, pergaulan tidak boleh diremehkan sebab akan menimbulkan efek yang cukup signifikan baik positif dan negatif.

Keempat, pengaruh dunia maya. Seperti yang telah maklum diketahui, saat ini seseorang dengan mudah mengakses video, gambar atau apapun di dunia maya. Kemudahan ini kemudian memicu para pengguna dunia maya untuk mengakses gambar atau video terlarang tersebut. Karena kemudahan inilah banyak remaja yang belum menikah memiliki rasa penasaran yang lebih kuat untuk ingin tau atau sekedar mencoba-coba untuk mengobati rasa penasaran itu. Akibatnya, tidak sedikit korban anak-anak remaja yang terjerumus dalam hal ini sehingga terancam kehilangan masa depan 
pendidikannya atau bahkan masa depanya secara umum sebab ia dikeluarkan dari sekolah atau bahkan tidak diakui oleh orang tuanya. Untuk itu, penggunaan dunia maya juga harus menjadi tanggung jawab bersama agar sesuai sasaran dan tidak disalah-gunakan.

\section{Problemtika Seksual}

1. Prostitusi

Dampak perubahan sosial yang disebabkan kemajuan ilmu pengetahuan dan teknologi salah satunya adalah kejahatan seksual. Melakukan hubungan seksual dengan orang yang belum halal secara agama semakin hari semakin memprihatinkan. Banyak anak-anak kecil yang mampu mengoperasikan internet baik melalui gadget, laptop, maupun alat komunikasi lainnya. Hal tersebut membuat para generasi muda 'terkotori' pikirannya sehingga tidak sedikit dari mereka yang terjerumus ke dalam kemaksiatan.

Munculnya kasus-kasus pemerkosaan, hamil di luar nikah, aborsi dan sebagainya menjadi bukti bahwa kemajuan ilmu pengetahuan dan teknologi pada umumnya dan internet khususnya membawa dampak ganda, positif dan negatif. Untuk dampak posistifnya, penulis tidak akan membahas lebih jauh, sebab hampir semua orang mengetahui dampak positif dari internet. Oleh sebab itu, maksud penulis dalam persoalan ini bukan hendak menghilangkan internet karena membawa dampak negatif. Namun, lebih kepada 'kontrol' sosial dengan keberadaan internet. Kontrol sosial yang penulis maksud adalah semua orang bahu-membahu untuk memerangi dampak negatif penggunaan internet.

Bagi orang yang mampu membuat kebijakan - Presiden misalnya, dapat memerintahkan Menkominfo untuk melakukan filterisasi terhadap situs-situs yang membahayakan bagi generasi muda. Selain itu, keikut-sertaan elemen masyarakat juga sangat dibutuhkan. Misalnya dengan menerapkan peraturan bagi warnet supaya tidak memberi pembatas ruangan agar semua orang yang ada pada tempat tersebut dapat mengetahui apa 
yang mereka akses. Selain itu, peran-serta orang tua, guru dan juga tokoh-tokoh agama sangat dibutuhkan sebagai kontrol sosial agar dampak negatif internet dapat diminilamalisir namun generasi muda tetap mamapu mengoperasikan internet untuk hal-hal yang positif.

Contoh konkrit maraknya kasus kejahatan seksual di Amerika misalnya dapat dilihat dari data statistik bahwa setiap ada tiga kelahiran, maka satu diantaranya adalah anak dari pasangan di luar nikah. ${ }^{5}$ Peristiwa ini tentu saja terkait dengan pola pikir bangsa Amerika yang terkenal dengan jargon kebebasannya. Namun secara tidak sadar, kebebasan mereka justru akan menjerumuskan mereka sendiri. Data statsistik pada tahun 1992 mencatat bahwa jumlah ibu yang hamil di luar nikah mencapai 1.2 juta orang. ${ }^{6}$ Dalam buku Dakwah Aktual yang ditulis oleh KH. Didin Hafifuddin menjelaskan kemerosotran moral bangsa Amerika begitu mengejutkan:

1). Tujuh dari sepuluh remaja putri dan delapan dari remaja putra sudah pernah melakukan hubungan seks dil uar nikah. Rata-rata usia mereka sekitar 15-16 tahun. 2). Setiap menit terjadi dua kehamilan remaja. 3). Kehamilan remaja antara umur 13-20 tahun jika dijumlahkan mencapai 40\% jumlah kehamilan yang ada di Amerika. 4). Dari kehamilan tersebut yang menjalani aborsi mencapai $50 \%$.

Dari referensi yang lain, penulis menemukan angka yang sedikit berbeda dari angka sebelumnya, namun perbedaan itu tidak begitu signifikan. Pada tahun 1959 ada sebuah siaran bahwa tujuh puluh lima persen anak di Barat merupakan anak haram. Kemerosotan moral ini kemudian mengundang simpatisan PBB untuk menggali kembali keabsahan angka tersebut, sehingga PBB mengadakan penelitian sendiri. "Tingkat kelahiran anak haram di Barat mencapai 60 persen, di bagian

${ }^{5}$ Didin Hafifudin, Dakwah Aktual. Jakarta: Gema Insani Press, 1998, 159.

${ }^{6}$ Ibid, 159. 
negara lain seperti Panama mencapai 75 persen, atau dengan kata lain, dari empat orang anak yang lahir, maka tiga diantaranya adalah anak haram dan itu terjadi di Amerika Latin." " Pada waktu yang sama dalam sebuah siaran menyebutkan bahwa di negara-negara Muslim, angka kelahiran anak di luar nikah sangat sedikit. di Mesir angka itu tidak lebih dari 1 persen. ${ }^{8}$

Dalam konteks anak-anak yang lahir di luar nikah kebanyakan dilakukan oleh pasangan "kumpul kebo". Frasa "kumpul kebo" dalam bahasa Indonesia merupakan istilah bagi orang-orang yang memiliki hubungan seksual di luar nikah, namun mereka tetap hidup bersama. Dalam konteks Barat, pasangan kumpul kebo yang punya anak haram ini memiliki jumlah yang sangat besar dengan populasi yang berbeda-beda dari berbagai negara. Jumlah pasangan kumpul kebo yang diukur dari usia 20-24 tahun adalah: Di Denmark 45\%, Swedia terpaut sedikit dibawahnya yaitu 44\%, Belanda 19\% dan Amerika Serikat $14 \%$.

2. Problematika Suka Kepada Sesama Jenis

Kaum Gay memiliki argumentasi bahwa dengan 'mengatasnamakan HAM dan tidak menggangu hak orang lain' mereka ingin mendapatkan label positif dan diakui oleh negara. Dalam kasus seperti ini, sebenarnya Barat memprakarsai praktik-praktik asusila yang berabad-abad dikecam oleh agama seperti praktik homo-lesbi dan sebagainya. Namun herannya mereka (Barat) membela mati-matian praktik tersebut dengan mengatas-namakan kebebasan HAM. $^{10}$ Herannya praktik ini justru diusung oleh para rohaniawan Kristen yang mana mereka

7 Husain Muhammad Yusuf, Muslim dan Tantangannya. terj. Salim Basharahil, Jakarta: Gema Insani Press, 1989, 124.

8 Ibid, 124.

${ }^{9}$ Francis Fukyama, terj. Masri Maris, Guncangan Besar: Kodrat Manusia dan Tata Sosial Baru. Jakarta: Gramedia Pustaka Utama, 2005, 54.

${ }^{10}$ Adian Husaini, Wajah Peradaban, 2. 
mulai mencari legalitas agama dari praktik-praktik ini. ${ }^{11}$ Padahal dalam Perjanjian Lama Kejadian 19: 4-19. disebutkan bahwa orang yang melakukan praktik homo dikecam dengan keras oleh Tuhan. Dalam kasus homo ini, para tokoh gereja awal seperti Clement Alexandria, St. John Cryisostom dan St. Agustine mengutuk perbuatan homo-seksual. Agustine menulis "Perilaku memalukan sebagaimana yang dilakukan di Sodom haruslah tetap dibenci dan dihukum di manapun, selamanya."12

Dalam masalah homo ini, al-Qur'an dan Alkitab kompak untuk melarangnya, namun perilaku umat Kristen tidak mencerminkan ajaran yang harus dilaksanakan oleh para pemeluknya. Masalah homo bukanlah masalah yang sepele bagi kehidupan manusia di bumi ini. Kitab suci, baik al-Qur'an maupun Bibel kompak melarang, sejarah para pembesar gereja pada masa lalu juga melarangnya, bahkan mengecam untuk selamanya. Herannya, kaum gay bukan hanya terjadi pada kalangan orang biasa, namun para rohaniawan Kristen. Mereka adalah tokoh, mereka adalah penutan, mereka adalah orang yang dijadikan imam bagi masyarakat. Kalau orang yang seharusnya menjadi suri tauladan sudah berbuat yang demikian, maka bagaimana dengan orang biasa? Tampaknya ini menjadi persoalan serius yang harus mendapatkan solusi.

Adian Husaini menuliskan tentang kondisi kaum gay yang terjadi pada kalangan umat Kristen, bahkan mereka memiliki jaringan yang kuat dan terorganisir. Kaum Katolik membuat gerombolan Gay dengan sebutan "Dignity" yang mengajarkan bahwa praktik homoseksual tidak bertentangan dengan ajaran Yesus. ${ }^{13}$ Kelompok ini menyebar di 22 negara. Bahkan di Israel ada kelompok gay yang disebut "Agundah". Kelompok ini sangat berpengaruh dalam kancah politik Israel, sampai-sampai banyak partai politik yang berebut meraih simpatisan kelompok

${ }^{11}$ Ibid, 4.

${ }^{12}$ Adian Husaini, Wajah Peradaban, 4.

${ }^{13}$ Ibid, 5. 
ini. ${ }^{14}$ Yang lebih mengherankan lagi adalah pada tahun 1976. Dalam pertemuan antar pembesar gereja di Minneapolis AS dideklarasikan bahwa kaum homoseksual adalah anak-anak Tuhan (homosexual persons are children of god). ${ }^{15}$ Sungguh suatu pernyataan yang menggelikan bahwa mereka adalah orang-orang yang seharusnya menjadi pendidik umat agar menjadi lebih baik, namun perilaku asusila mereka malah ingin disebarkan kepada orang lain dan mencari legalitas negara maupun agama.

Kaum Protestan juga tidak kalah hebohnya dengan perilaku para rohaniawan Katolik. Pada bulan November 2003 Gereja Anglikan (Protestan) di New Hampshire mengangkat seorang homoseksual sebagai Uskup ${ }^{16}$ bernama Gene Robinson. Robinson telah dikenal masyarakat sebagai seorang gay yang telah hidup bersama pasangan sejenisnya selama 14 tahun yang bernama Mark Andrew. ${ }^{17}$

Jika di nalar, perilaku gay/lesbi ini tentunya tidak akan pernah tepat jika dipraktikkan secara universal, sebab jika hal ini dilakukan oleh semua orang di dunia, maka yang terjadi adalah semua umat manusia di bumi akan musnah dalam jangka waktu 100 tahun, karena sudah tidak ada lagi penerus di muka bumi ini.

Selain kenyataan di atas, masih ada yang lebih parah lagi dengan menganggap bahwa Yesus tidak menikah itu memiliki latar belakang yang negatif. Biasanya lelaki tidak menikah memiliki tiga sebab, tidak mampu melakukannya, tidak ada perempuan atau jangan-jangan homoseksual? ${ }^{18}$ Dugaan yang dilancarkan oleh kaum gay ini sesungguhnya merupakan sebuah

\footnotetext{
14 Ibid, 7-15.

15 Ibid, 5.

16 Uskup adalah rohaniawan Katolik, Anglikan, Lutheran atau Yunani Ortodoks yang kedudukannya lebih tinggi daripada imam. Ia memiliki hak untuk sakramen penguatan dan mentahbiskan imam. Dan bertugas mengorganisasi pekerjaan dan tugas gereja di wilayah tertentu. Ebta Setiawan, Kamus Besar Bahasa Indonesia. Digital.

17 Adian Husaini, Wajah Peradaban ..., 7.

18 Ibid, 54. dari Muhammad Mustafa al-Azami, The History of the Qur'anic Text. Uk Islamic Academy, 269.
} 
upaya agar perilaku mereka diterima dan disahkan oleh agama. Dengan demikian, maka gay dalam Kristen menjadi sebuah komunitas resmi, bukan lagi tabu.

Memang kelompok gay sudah bukan lagi menjadi kaum yang dianggap tabu di mata publik, khususnya di negara-negar Barat. Di Amerika tercatat banyak perusahaan besar seperti IBM, Subaru, Anheuser-Busch, British Airwaay yang menggunakan jasa para kaum gay ini untuk mengiklankan produk mereka. Semua jasa iklan menggunakan figure gay, baik melalui televisi, majalah, reklame dan bahkan dengan mempermak kendaraan umum menjadi mitra bisnis mereka, karena mereka menyadari bahwa kaum Gay adalah kelompok yang sangat berpengaruh dalam negara tersebut. Implikasinya adalah iklan tersebut memperoleh tempat yang cukup istimewa dimata publik, sehingga iklan-iklan yang menggunakan jasa kaum gay akan laris manis.

Orang-orang yang meremehkan peran serta kaum gay dalam periklanan akan terancam kehilangan momentum berharga sebab mereka adalah kelompok istimewa dan berharga dimata publik. Peran serta kaum gay dalam pengiklanan dinilai membawa keuntungan yang besar dalam bisnis mereka. Dengan demikian maka wajar bila kaum gay tergolong orang-orang yang berpenghasilan tinggi atau dapat dikatakan bahwa mereka adalah kelompok orang-orang kaya yang berpengaruh dalam lingkungannya. Menurut majalah Gene yang merupakan salah satu media cetak terbesar di Amerika mencatat bahwa rata-rata penghasilan pria gay $\$ 92.000$. Di tahun 1990 penghasilan mereka tercatat dalam sensus penduduk, rata-rata $\$ 58.000 .^{19}$

Jumlah kaum Gay yang ada di Amerika memang bisa dikatakan cukup besar, baik dari segi jumlah maupun pengaruhya. Marc Gobe mencatat bahwa jumlah kaum gay di Amerika diperkirakan 3 sampai 10 persen populasi orang

${ }_{19}$ Marc Gobe, Emotional Branding, Paradigma Baru untuk. Menghubungkan Merek Kepada Pelanggan, terj. Bayu Mahendra, Jakarta: Erlangga, 2005) 65-66. 
dewasa. ${ }^{20}$ Data lain juga disampaikan oleh Zakir Naik dalam ceramahnya, yang mengambil data statistik Amerika bahwa jumlah homoseksual di Amerika sebanyak 25 juta orang. ${ }^{21}$

Menurut majalah Seventeen ada sebanyak 54 persen remaja merasa nyaman dengan homoseksualitas, bandingkan dengan tahun 1991 yang hanya 17 persen. Dan yang tidak kalah menariknya adalah pengaruh mereka terhadap pasar bahkan khalayak umum. Dengan demikian, maka dapat dikatakan bahwa kaum homo - khususnya di Amerika - bukan lagi kelompok yang termarjinalkan atau tabu untuk dipublikasikan, akan tetapi justru sebaliknya, mereka mendapatkan simpatisan publik yang sangat besar dan bahkan menguntungkan perusahaan-perusahaan yang mengunakan jasa kaum gay.

Penulis menyadari sepenuhnya bahwa apapun itu kerusakan moral atau norma-norma agama - demi urusan uang akan ditempuh oleh Barat, khususnya Amerika. Bahkan ada even tahunan untuk para kaum Gay yang biasanya diselenggarakan pada bulan Agustus dengan sebutan Gay Parade bagi kaum gay se-Eropa atau bahkan se-dunia yang diselenggarakan di sepanjang kanal Amsterdam. ${ }^{22}$

\section{Solusi dalam al-Qur'an}

1. Solusi Prostitusi

a. Penciteraan Buruk

Solusi pertama yang ditawarkan oleh al-Qur'an adalah langkah antisipasi sebelum terjadi kejahatan seksual. Langkah antisipasi ini adalah lebih menekankan aspek psikis. Dalam alQur'an Allah berfirman dalam surat al-Isrāa [17] ayat 32 sebagai berikut:

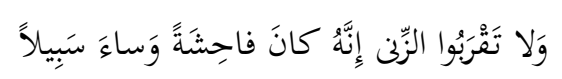

${ }^{20}$ Gobe, Emotional ..., 65.

${ }^{21}$ Zakir Naik, Mengapa Barat Kembali ke Islam. Dār al-Islam Club Malaysia \& Islamic Research Fundation, 1998, CD I, menit ke-44.

22 Wahyuningrat, et. al. Negeri Van Oranje. Yogyakarta: Benteng Pustaka, 2009, 164. 
Janganlah kamu sekalian mendekati zina, sesungguhnya zina itu adalah perbuatan keji dan cara terburuk.

Orang yang akan melakukan seksual atau berzina membutuhkan waktu yang tidak singkat (membutuhkan proses). Sebab, secara naluriah, sangat kecil kemungkinannya seseorang langsung melakukan perzinaan tanpa adanya proses pendekatan. Dalam hal inilah al-Qur'an berperan bahwa proses untuk menuju hal tersebut harus dijauhi. Mengenai bentuk dan modelnya seperti apa, al-Qur'an tidak menegaskan secara spesifik. Namun secara umum, al-Qur'an membicarakan substansinya, bukan tekniknya. Substansinya adalah jangan mendekati zina, apapun bentuknya. Baik melalui cara berkomunikasi, cara berpakaian, cara berbicara, cara bergaul dan sebagainya. Untuk itu, bentuk apapun yang dilakukan seseorang, jika ia akan menjurus kepada bentuk perzinaan, maka harus dipotong pada saat itu.

\section{b. Praktik Hijab}

Pemerkosaan yang terjadi di negara-negara maju, khususnya Amerika sangat besar kemungkinannya dikarenakan jumlah kaum wanita yang melebihi pria dan budaya Barat yang tidak benar. Pada persoalan ini, Islam menawarkan solusi bijab. Hijab adalah pakaian yang menutupi seluruh anggota tubuh, kecuali telapak tangan dan wajah. Dengan catatan bukan pakaian yang transparan dan memperlihatkan bentuk tubuh. Sebab tujuan utama pemakaian hijab adalah untuk menghidari godaan kaum pria. Hijab juga memiliki arti yang sangat luas, yakni bukan hanya dari segi pakaian saja, namun juga tutur kata, perilaku, pikiran dan hati. Oleh sebab itu, orang yang mengenakan pakaian ala Muslimah, namun tutur sapanya menarik seseorang untuk melakukan maksiat, maka bijab dari segi tutur sapa belum terpenuhi, begitu pula seterusnya.

Orang-orang Barat memiliki jargon 'kebebaskan pergaulan'. Berbagai hal dideklarasikan sebagai kebebasan 
HAM dan bahkan cara berpakaian yang bebas pula. Ada sebagian orang yang menyatakan bahwa berpakaian ala Muslimah dengan menggunakan hijab dinilai tidak sopan di Barat, sementara di tempat lain seperti di India, orang tidak sopan jika tidak mengenakan pakaian ala India dengan menggunakan selendang panjang, dan kerudung walaupun rambutnya tetap kelihatan, dan kelihatan pula pusarnya.

Cara berpakaian ala India, jika berada di Barat, akan diangap kampungan dan kurang etis, sementara sebaliknya, ketika orang Barat ke India, maka orang Barat juga akan diberlakukan demikian, yakni mereka orang-orang Barat berpakaian tidak sopan. Lalu yang menjadi tolak ukur yang mana? Barat atau India? Tidak satupun jawaban yang dapat memuaskan seluruhnya! Yang perlu untuk dipertimbangkan adalah mengenai pantas dan tidak pantas itu adalah urusan lokalitas.

Tiada hakim yang menengahi masalah ini kecuali Islam. Islam tampil beda untuk mempertarungkan aturan mana yang sekiranya tepat untuk dipakai di India maupun di Barat. Islam menembus ruang dan waktu dalam semua urusan manusia, Islam bukan hanya mengajarkan spiritualitas semata tanpa melihat problematika yang ada dan penyelesaiannya. Zakir Naik memberikan suatu ilustrasi yang menarik dalam hal menyelesaikan persoalan banyaknya kasus pemerkosaan di Barat.

Jika ada dua gadis kembar yang sama-sama cantik, yang satu didandani dengan pakaian ala Barat, dengan berpakaian ketat dan memakai rok mini, sementara yang satunya lagi berpakaian ala Muslimah dengan menutupi seluruh tubuh kecuali tangan dan wajah, lalu kedua gadis tersebut berjalan di kerumunan kaum pria, gadis manakah yang akan digoada? ${ }^{23}$

${ }^{23}$ Zakir Naik, Wanita dalam Islam ..., CD. II, menit ke-6. 
Jika syari'at Islam ini diterapkan di Barat, apakah kejahatan seksual akan bertambah, stagnan, atau menurun? Orang Barat yang menyadari bahwa sesungguhnya Islam adalah agama yang logis, menjawab persoalan yang sedang dihadapi serta menembus sekat ruang dan waktu. Islam bukan untuk orang Arab, bukan untuk orang Amerika, bukan untuk orang Indonesia, namun Islam untuk seluruh umat manusia.

\section{Solusi Kawin Sesama Jenis}

Homo dan lesbi adalah problem sosial yang melanda dunia akhir-akhir ini, bahkan sampai ke Indonesia. Di Indonesia ada sebuah buku yang berjudul "Indabnya Kawin Sesama Jenis" yang diterbitkan oleh sejumlah mahasiswa di IAIN Semarang. Namun jika ditelusuri sesungguhnya akarnya adalah dari Barat. Permasalahan ini sesungguhnya bukanlah persoalan baru. Dalam catatan sejarah, selalu ada perilaku yang menyimpang dari sekian banyak umat manusia, namun persoalannya adalah apakah yang ditawarkan Islam dalam mengatasi problematika ini?

Dalam masalah homo, al-Qur'an memberikan ilustrasi sejarah bahwa kaum homo sudah ada sejak nabi Luth. Dan alQur'an merekam mereka agar direnungkan bagi umat manusia. Allah berfirman diberbagai ayat dalam al-Qur'an: al-A'raf ayat 80-81, Hūd 78, al-Shüarà' 165-166, al-Naml 55 dan al'Ankabūt 29. Disini penulis akan mencantumkan dua ayat dari surat al-A'rāf. Allah brfirman:

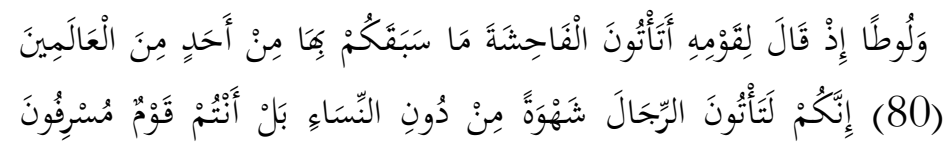

Dan (Kami juga telah mengutus) Lut (kepada kaumnya). (Ingatlah) tatkala dia berkata kepada mereka: "Mengapa kamu mengerjakan perbuatan fähisyab itu [homo seksual], 
yang belum pernah dikerjakan oleh seorangpun (di dunia ini) sebelummu?" Sesungguhnya kamu mendatangi lelaki untuk melepaskan nafsumu (kepada mereka), bukan kepada wanita, malah kamu adalah kaum yang melampaui batas.

Cara yang diajarkan oleh al-Qur'an agar terlepas dari melencengnya hasrat seksual dari yang semestinya adalah dengan memandang bahwa homo itu merupakan perbuatan yang keji dan melampaui batas. Sebab, bila masyarakat sudah merasa bahwa homo adalah tindakan yang biasa saja, maka yang terjadi adalah pertumbuh-suburan kekejian itu sehingga menjadi penyakit kronis yang sukar untuk diobati. Dengan upaya pencitraan ini kiranya akan terbentuk sebuah pengaruh pada masyarakat bahwa perbuatan itu adalah abnormal. Oleh karenanya, homo haruslah diberi label yang negatif.

Dengan memberi label negatif inilah bibit-bibit homo yang akan muncul bisa diminimalisir. Dalam hal ini, al-Qur'an mengutuk bahwa perbuatan tersebut sebagai sebuah keburukan, baik dipandang dari sisi Tuhan maupun makhluk, dipandang buruk oleh individu maupun masyarakat. Jadi, jika melihat pada pengajaran al-Qur'an aspek utama yang harus terpenuhi adalah penilaian lingkungan. Jika lingkungan sudah memandangnya sebagai hal yang wajar, maka homoseksual akan sulit diberantas.

Solusi kedua yang diajarkan oleh al-Qur'an adalah dijelaskan dalam surah Hūd. Allah memberikan sebuah rekaman cerita tentang nabi Lūt dan kedua puterinya; Allah berfirman dalam surat Hūd ayat 78:

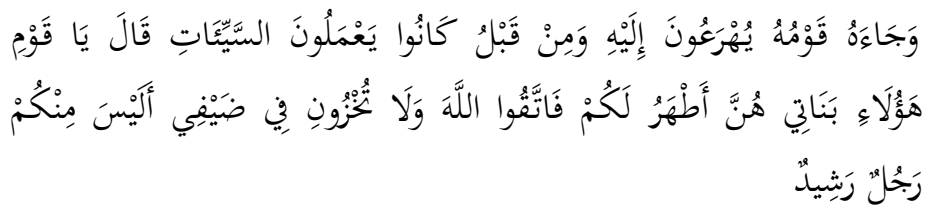


Dan datanglah kepadanya kaumnya dengan bergegasgegas. Sejak dahulu mereka selalu melakukan perbuatanperbuatan yang keji [homoseks]. Lūt berkata: "Hai kaumku, inilah putri-putriku, mereka lebih suci bagimu, maka bertakwalah kepada Allah dan janganlah kamu mencemarkan (nama)ku terhadap tamuku ini. tidak adakah di antaramu seorang yang berakal?."

Dalam ayat ini Allah menekankan kepada orang yang memiliki akal untuk merenungkan bahwa manakah yang lebih baik, antara menikah dengan lawan jenis atau sesama jenis? Pernikahan normal ditekankan oleh al-Qur'an kepada orang yang berakal. Itu artinya jika mereka melakukan homoseks tersebut, dalam benaknya akan timbul suatu ketidak-nyamanan dalam menjalankan kehidupan dengan sesama jenis. Pesan alQur'an yang menekankan aspek rasionalitas adalah untuk memberikan pertimbangan bahwa seks dengan lawan jenis lebih nyaman dan tenteram, karena sesungguhnya laki-laki dan perempuan diciptakan untuk saling melengkapi antara satu dengan yang lainya.

Wanita ditabiatkan memiliki sifat yang lemah lembut dan lelaki diciptakan sebagai manusia yang lebih kuat dan kasar. Untuk itu, dalam menjalani kehidupan ini, siapapun dia, di manapun ia berada dan kapanpun waktunya pasti disuatu saat atau dalam keadaan tertentu membutuhkan sikap yang lemah lembut wanita dalam mengarungi kehidupan. Semantara di sisi lain, pasti disuatu saat orang akan mengalami kejadian-kejadian yang membutuhkan kekuatan fisik/tenaga, walaupun sekali atau berkali-kali dalam hidupnya. Oleh sebab itu, lebih tepat dan benar jika dalam menjalani perkawinan ini adalah berlainan jenis. Selain itu, pernikahan dengan lawan jenis juga berguna untuk menyambungkan keberlangsungan kehidupan manusia. Sebab, jika semua orang menilai dan nyaman bahwa homo itu adalah baik serta semua orang mempraktikkan hal 
tersebut maka kehidupan manusia di bumi ini akan musnah karena tidak ada lagi yang melahirkan keturunan.

Banyak orang-orang yang memutar otaknya untuk menemukan sebuah obat ataupun ramuan yang mujarab guna menyembuhkan berbagai penyakit, itu semua dilakukan demi kelestarian kehidupan umat manusia. Banyak pasangan yang telah lama menikah, namun belum juga memiliki anak, mereka tetap berusaha agar memiliki keturunan. Karena dalam Islam anak merupakan aset yang sangat berharga. Anak yang salih dan mau mendoakan kedua orang tuanya ${ }^{24}$ merupakan salah satu aset yang paling berharga di dunia.

Usaha-usaha keras yang dilakukan oleh para peneliti, ilmuan dokter dan ahli-ahli lainnya, tujuannya tidak lain hanyalah untuk menjaga dan melestarikan kehidupan manusia di bumi ini. Dengan hadirnya orang-orang homo ini akan dibawa kemana umat manusia di bumi ini kelak? Menikah dengan wajar, itulah solusi yang diajarkan oleh al-Qur'an seperti tawaran nabi Lūt as. kepada kaumnya untuk menikahi anak perempuannya - maupun sunnah Nabi. Mengutip pernyataan Adian Husaini, "Binatang saja masih tahu lawan jenisnya, mengapa manusia tidak?”

\section{E. Kesimpulan}

Perkembangan ilmu pengetahuan dan teknologi yang di usung oleh Barat membawa dampak yang signifikan terhadap negara-negara Timur, khususnya negara-negara Islam. Mereka memiliki anggapan bahwa 'jika ingin maju seperti Barat, maka harus meniru Barat' padahal, Barat sendiri masih menyimpan masalah besar terutama kemerosotan moral seperti perzinaan dan homolesbi.

Prostitusi adalah perkara serius yang harus dicegah sejak dini dan menjadi tanggung jawab bersama agar perkara kejahatan ini

${ }^{24}$ Abū al-Ḥusain Muslim bin al-Hajjāj bin Muslim al-Qushairȳ al-Naisabūrȳ, Saḥịh Mustimm. Beirut: Dār al-Afā al-Jadidah, t.th, nomor hadis 4310. 
dapat dihilangkan atau diminimalisir. Solusi yang di tawarkan oleh alQur'an dalam memberantas atau mengurangi prostitusi adalah dengan cara memutus mata rantai yang akan menjurus kesana. Konsep ini diterangkan dengan larangan 'Janganlah kamu sekalian mendekati zina, karena zina itu perbuatan yang keji Solusi kedua yang ditawarkan oleh al-Qur'an adalah mengenakan bijab.

Dalam persoalan homo-lesbi, al-Qur'an menawarkan solusi lewat pencitraan. Homo dan lesbi dalam al-Qur'an haruslah dinilai buruk oleh seluruh lapisan masyarakat. Sebab, jika semua orang menganggap baik dan bahkan mempraktikkan hal ini, kehidupan manusia akan musnah karena tidak akan ada lagi yang memiliki anak. Solusi kedua yang ditawarkan oleh al-Qur'an dalam menghadapi kaum homo-lesbi adalah dengan cara menikah dengan wajar, yaitu dengan menikahi lawan jenis. 


\section{DAFTAR PUSTAKA}

al-Azami, Muhammad Muștafa. The History of the Qur'anic Text, Uk Islamic Academy, 2010.

Aliade, Mircea. The Encyclopedia of Religion, New York: Macmillan Publishing Company, 1987.

Fukyama, Francis. terj. Masri Maris, Guncangan Besar: Kodrat Manusia dan Tata Sosial Baru, Jakarta: Gramedia Pustaka Utama, 2005.

Gobe, Marc. Emotional Branding, Paradigma Baru untuk Menghubungkan Merek Kepada Pelanggan, terj. Bayu Mahendra, Jakarta: Erlangga, 2005.

Hafifuddin, Didin. Dakwah Aktual, Jakarta: Gema Insani Press, 1998.

http:/ / boombastis.com/negara-dengan-kasus-pemerkosaantertinggi/5797.

http://news.okezone.com/read/2015/03/31/18/1126749/10-negarakasus-pemerkosaan-tertinggi

http://www.religion-facts.com/id/u3. di akses tanggal 21-11-2015

Muslim, Abū al-Husain Muslim bin al-Hajjaj bin Muslim al-Qushairy alNaisabūry, Sahịḥ Muslim, Beirut: Dār al-Afāq al-Jadidah, tt.

Setiawan, Ebta. Kamus Besar Bahasa Indonesia. Digital.

Wahyuningrat, et. al. Negeri Van Oranje, Yogyakarta: Benteng Pustaka, 2009.

Yusuf, Husain Muhammad. Muslim dan Tantangannya, Terj. Salim Basharahil, Jakarta: Gema Insani Press, 1989. 
Spiritualis, vol. 4, no. 1, Maret 2018|90

Zakir Naik, Abdul Karim. Wanita dalam Islam: Modern atau Ketinggalan Zaman, Malaysia: Islamic Research Fundation, 2000.

--------, Mengapa Barat Kembali ke Islam, Dār al-Islam Club Malaysia \& Islamic Research Fundation, 1998. 